〈報 告〉

\title{
末梢静脈カテーテル留置期間と血流感染および静脈炎発生の関連性に関する検討
}

\author{
多湖ゆかり ${ }^{1,2)} \cdot$ 谷 久弥 ${ }^{1)} \cdot$ 森兼 啓太 ${ }^{2,3)}$
}

\section{Relevance of The Duration of Peripheral Intravenous Catheterization to Bloodstream Infection and Phlebitis}

\author{
Yukari TAGO ${ }^{1,2)}$, Hisami TANI ${ }^{1)}$ and Keita MorIKANE ${ }^{2,3)}$ \\ 1) Infection Control Team, Hikone Municipal Hospital, \\ 2) Peripheral Intravenous Catheter-related Infections Surveillance Study Group, \\ 3) Division of Infection Control, Yamagata University Hospital \\ (2013 年 11 月 27 日 受付 $\cdot 2013$ 年 12 月 9 日 受理)
}

\begin{abstract}
要 旨
CDC の Guidelines for the Prevention of Intravascular Catheter-Related Infections, 2011 の発出 を受け, 末梢静脈カテーテルの標準的な留置期間を 4 日毎から 7 日毎に変更した. 留置期間が適 切か否かを評価するため変更後 6 ヶ月間 (2011 年 7 月〜 12 月)の末梢静脈カテーテルに関連する BSI と静脈炎のデータ解析をした. 延べ留置日数 2,784 日, ライン使用本数 989 本に対して, BSI 発生は 2 件であり, 1000 ライン日あたり 0.72 件であった. 発生日はどちらも留置 3 日目であっ た. 静脈炎 (INS 基準 : 2 + 以上) は 14 件で, 3 日以内と 4 日以上を比較して静脈炎発生率に有意差 は見られなかった，従って，末梢静脈カテーテルをルーチンに $3 \sim 4$ 日毎に刺し替える必要はな い. 刺入部の観察を重視した上での 7 日毎の刺し替えは, 患者の苦痛軽減やスタッフの労力削減 を図る上でむしろ好ましいと考える.
\end{abstract}

Key words : 末梢静脈カテーテル，血流関連感染，静脈炎，サーベイランス，留置期間

\section{はじめに}

CDC の Guidelines for the Prevention of Intravascular Catheter-Related Infections, 2011 (以下, Guidelines 2011) ${ }^{1)}$ の発出を受け, 末梢静脈カテーテル(以下, 末梢 ライン)の標準的な留置期間を 4 日毎から 7 日毎に変更 した。留置期間決定には，これまでに当院で実施してい た末梢ライン関連イベントのサーベイランスと全国の 14 施設が参加する (当院も所属) 末梢ライン関連 BSI サーベイランス研究会のデータも参考にした. Guidelines2011 では，末梢ラインおよびミッドラインカテー テルの交換は, 成人では感染や静脈炎のリスクを低減す るために 72〜96 時間よりも頻回に交換する必要はな い1）と記載されて抢り, 留置期間の上限は示していな

1)彦根市立病院感染対策室 (ICT), ${ }^{2}$ 末梢ライン関連感染サー ベイランス研究会, ${ }^{3)}$ 山形大学医学部附属病院感染制御部
い. 一方で，静脈投与期間が 6 日を超えると想定され る場合はショートタイプの末梢静脈カテーテルのかわり にミッドラインカテーテルまたは末梢抻入型中心静脈力 テーテル(Peripherally inserted central-line catheter, PICC)を使用すること吕と記載がある。しかし，日本で はPICCの挿入や使用に医療従事者が慣れておらず，留 置期間が 6 日を超える末梢ラインすべてをPICCに移行 することは現実的には困難である。また，輸液セットの 交換に関して, 血液, 血液製剂, 脂肪乳剂の投与を行っ ていない患者に招いて, 二次的セットや追加器具を含む 連続使用する輸液セットは，96 時間以上の間隔を空 け，少なくとも 7 日毎に交換すること1) と記載されてい る.これらを含め勘案した結果, 当院での末梢ラインの 留置期間を 4 日毎から 7 日毎に変更した。そして留置 期間が適切か否かを評価するため, 変更後の BSI と静 脈炎のデータ解析をした。 
方法

\section{1. 調査期間}

当院での標準的な末梢ライン留置期間を 7 日毎に変 更後 6 ヶ月間 (2011 年 7 月〜 12 月)の末梢ラインサーベ イランスの BSI と静脈炎のデータを後方視的に解析を した. 比較として 2010 年 3 月〜 2012 年 12 月までの末 梢ライン関連 BSI サーベイランス研究会のデータを参 考にした。

\section{2. 対象}

当院の呼吸器 ·循環器科等の混合病棟に入院する末梢 ライン留置患者を対象とした．短時間の翼状針による刺 入や日をまたがない末梢ライン留置患者は対象から除外 した.

\section{3. 手法}

末梢ラインサーベイランスは CDC のサーベイランス システムである National Healthcare Safety Network (NHSN) や2), 日本のデバイス関連感染サーベイランス である Japanese Healthcare-Associated Infections Surveillance (JHAIS) および Japan Nosocomial Infections Surveillance (JANIS) では対象となっていないため, 当 院も所属し全国の 14 施設が参加する末梢ライン関連 BSI サーベイランス研究会で構築されたサーベイランス システムを用いた。

感染管理認定看護師が使用日数や抜去の理由, 抜去時 所見などのデータを収集し，共通のワークシートを用い て集計した(図 1).

同研究会におけるBSI の疾患定義を表 1 に示すが， NHSN の中心ライン関連血流感染判定基準の LCBI（検 查確定血流感染)に加えて, CSEP (臨床的敗血症) も採
用している．静脈炎は，アメリカの輸液看護学会 (Infusion Nurse Society, INS)（表 2)のスケールを使用して㧤 り，2+以上の所見を静脈炎と定義している.

\section{4. 当院での BSI 予防策実施事項}

末梢ラインの留置期間と輸液セットを標準的に 7 日 毎に交換する以外に，当院で行っている BSI 予防策実 施事項としては，下記が挙げられる。

・末梢静脈カテーテル挿入・管理の訓練

・手指衛生・手袋着用 (ミキシング ·挿入 · 交換 ·ア クセス・ドレッシング取り扱い時等)

・末梢静脈カテーテル插入前に $70 \mathrm{w} / \mathrm{v} \%$ アルコール で皮膚消毒

・可能な限り上肢に挿入

・透明ドレッシング使用 (観察) 7 日毎の交換

- 電子カルテへの刺入部観察項目の記載 (各勤務 1 回）

・静脈炎・感染徵候がある場合の速やかなカテーテル 除去

・臨床的に 7 日以上留置が必要な理由がある場合は 観察を充分に行う。

\section{5. 統計処理}

末梢ライン留置期間の 3 日以内と 4 日以上の静脈炎 発生率，発赤発現率を比較する際に，フィッシャーの直 接確率を用いて検定を行った．有意水準は $\mathrm{p}<0.05$ とし た。

\section{結 果}

研究期間中の末梢静脈カテーテル延べ留置日数は 2,784 日，ライン使用本数 989 本，平均留置日数 2.8 日

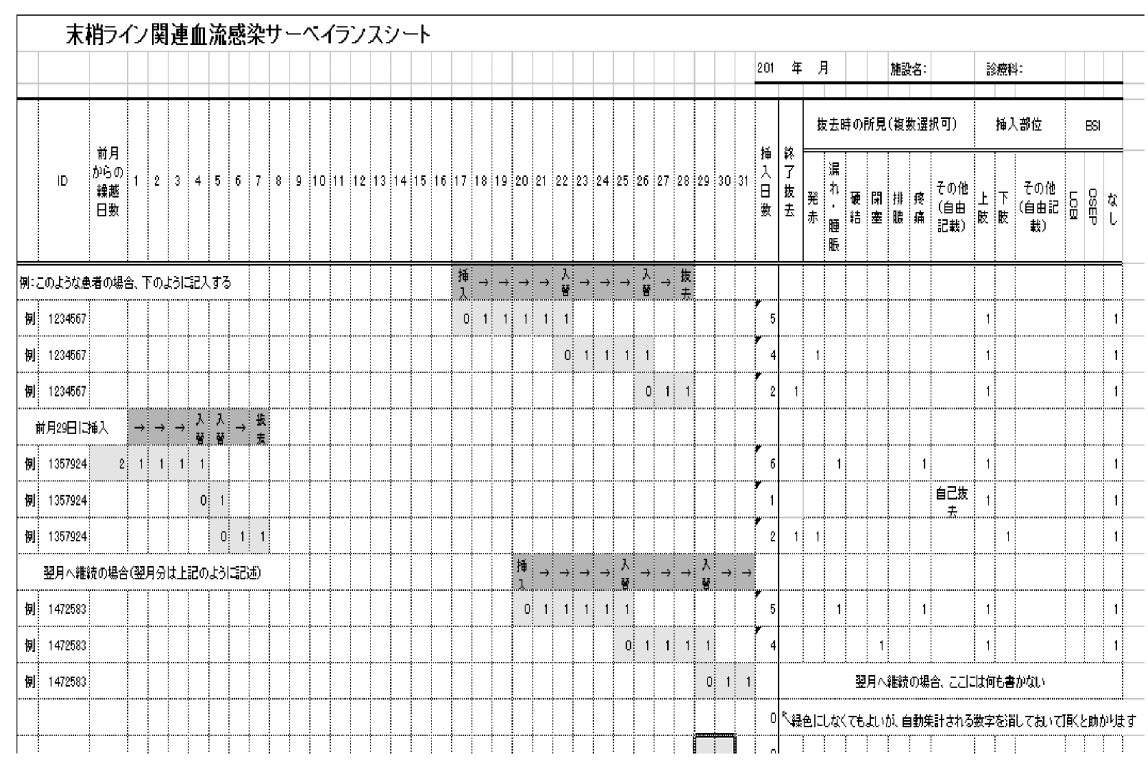

図 1 末梢ライン関連血流感染サーベイランスシート 
太検査確定血流感染 $(\mathrm{LCBI})$ ：判定基準 $\mathrm{A}$ または判定基準 $\mathrm{B}$ のいずれかを満たすこと

判定基準 $A$ ：以下のすべてを満たすこと

1, 患者の1回以上の血液培養から一般の皮膚污染菌※以外の病原体が分離される

2, 血液から培養された微生物は, 末梢ラインに関連しない他の部位の感染と関係がない.

判定基準 $\mathrm{B}$ : 以下のすべてを満たすこと

1, 患者が以下の徵候や症状を少なくとも 1 つ有している: 発熱 $\left(>38^{\circ} \mathrm{C}\right)$, 悪寒戦慄, 低血圧.

2, 徵候や症状や陽性の検査結果が, 末梢ラインに関連しない他の部位の感染と関係がない.

3, 一般の皮膚污染菌※が別々の機会に採取された 2 回以上の血液培養検体から培養される.

※類ジフテリア [Corynebacterium 属], バシラス属 [B. anthracisは除く], Propionibacterium 属, コアグラーゼ陰性ブドウ球菌 [S. epidermidis を含む], viridans 群連鎖球菌, Aerococcus 属, ミクロコッカス属

丸臨床的敗血症(CSEP)：以下のすべてを満たすこと

1, 他に確認された原因がなく, 以下の臨床的徵候や症状を少なくとも 1 有している：発熱 $\left(>38^{\circ} \mathrm{C}\right)$, 悪寒戦慄, 低血圧.

2, 血液培養がなされていない, あるいは血液中に微生物が検出されない.

3, 末梢ラインと関連しない他の部位に明らかな感染がない。

4, 医師が敗血症に対する治療(抗菌薬治療や，カテーテル抜去とそれに引き続く解熱など）を開始する.

表 2 アメリカの輸液看護学会(INS)のスケール

\begin{tabular}{|c|c|}
\hline $1+$ & 刺入部に発赤あり（疼痛の有無は問わない） \\
\hline $2+$ & 刺入部に「発赤および/もしくは腫脹」を伴う疼痛あ \\
\hline $3+$ & $\begin{array}{l}\text { 刺入部に「発赤および/もしくは腫脹」を伴う疼痛あ } \\
\text { り, 赤い索条硬結が触知可能 }\end{array}$ \\
\hline $4+$ & $\begin{array}{l}\text { 刺入部に「発赤および/もしくは腫脹」を伴う疼痛あ } \\
\text { り, 赤い索条, 長さ } 1 \text { インチ }(=2.54 \mathrm{~cm}) \text { 以上の索条 } \\
\text { 硬結が触知可能, 排膿あり }\end{array}$ \\
\hline
\end{tabular}

であった. BSI は 2 件発生し, 1000 ライン日あたり 0.72 件であった(表 3). また, 2 件とも末梢ライン留置 後 3 日目に発生し, 起因菌はそれぞれ, MRSA, Bacillus cereus であった.

静脈炎は 14 件，1000 ライン日あたり 5.0 件であり， 図 2 に示すと抢り，末梢ライン留置期間 3 日以内の発 生が 8 件 $(57 \%) ， 4$ 日以上の発生が 6 件 $(43 \%)$ であっ た. 発赤 (INS 基準 : $1+$ 以上) は 111 件であり，末梢ラ イン留置期間 3 日以内の発生が 84 件 (76\%) で 4 日以上 の発生が 27 件 (24\%) であった (図3). 末梢ライン留置 期間 3 日以内と 4 日以上を比較して静脈炎発生率 $(\mathrm{P}=$ $0.37)$, 発赤発生率 $(\mathrm{P}=0.19)$ ともに有意差は見られなか った (表 4, 表 5). 末梢ライン留置期間 4 日以上のライ ンのみに限ると，BSI は発生して抢らず，静脈炎発生は 1000 ライン日あたり 2.16 件と全体 (5.0 件)の半分以下 の頻度であった。

末梢ライン関連 BSI サーベイランス研究会の結果で も静脈炎発生日の傾向は同様で有り, 静脈炎の発生 350 件のうちの $70 \%$ が末梢ライン留置期間 3 日以内に, $80 \%$ が 4 日以内に発生している.
表 3 末梢ラインサーベイランス結果の当院と研究会の比較

\begin{tabular}{|c|c|c|}
\hline & 当院データ & 研究会データ \\
\hline & $\begin{array}{c}2011 \text { 年 } 7 \text { 月 } \\
12 \text { 月 }\end{array}$ & $\begin{array}{l}2010 \text { 年 } 3 \text { 月 } \\
\sim 2012 \text { 年 } 12 \text { 月 }\end{array}$ \\
\hline 延べ留置日数 & 2,784 & 55,291 \\
\hline BSI 件数 & 2 & 7 \\
\hline $\begin{array}{l}\text { BSI 発生率 } \\
(1000 \text { カテーテル日あたり) }\end{array}$ & 0.72 & 0.13 \\
\hline ライン使用本数 & 989 & 19,527 \\
\hline $\begin{array}{l}\text { 静脈炎発生件数 } \\
\text { 静脈炎(INS 基準: } 2+\text { 以上) }\end{array}$ & 14 & 350 \\
\hline $\begin{array}{l}\text { 静脈炎発生率 } \\
\text { (1000 カテーテル日たたり) }\end{array}$ & 5.0 & 7.7 \\
\hline 平均留置日数 & 2.8 & 2.8 \\
\hline
\end{tabular}

考察

改訂される以前の CDC の Guidelines for the Prevention of Intravascular Catheter-Related Infections（以下, Guideline2002)では，末梢静脈カテーテルの交換に関し て, 静脈炎防止のため, 成人の患者では少なくとも 72 〜96 時間毎に末梢静脈カテーテルを交換すること年と記 載されている．末梢静脈カテーテルに関するこれまでの 研究4,5)でも 96 時間以内での刺し替えを適正使用とする 前提で調査が行われている。しかし，96 時間以上の留 置により感染率が高くなったという報告は無く, Guideline2002 の根拠はあいまいなままであった. 2007 年に Webster らは，合併症が発生した時に末梢静脈カテー テルを再扦入した患者(介入群)と 3 日ごとに交換(対照 群)した患者との比較を行った ${ }^{6)}$. 結論としてはルーチ ンで 3 日毎に交換することに比べて，臨床的所見が あった時に末梢静脈カテーテル交換をした群がより多く 


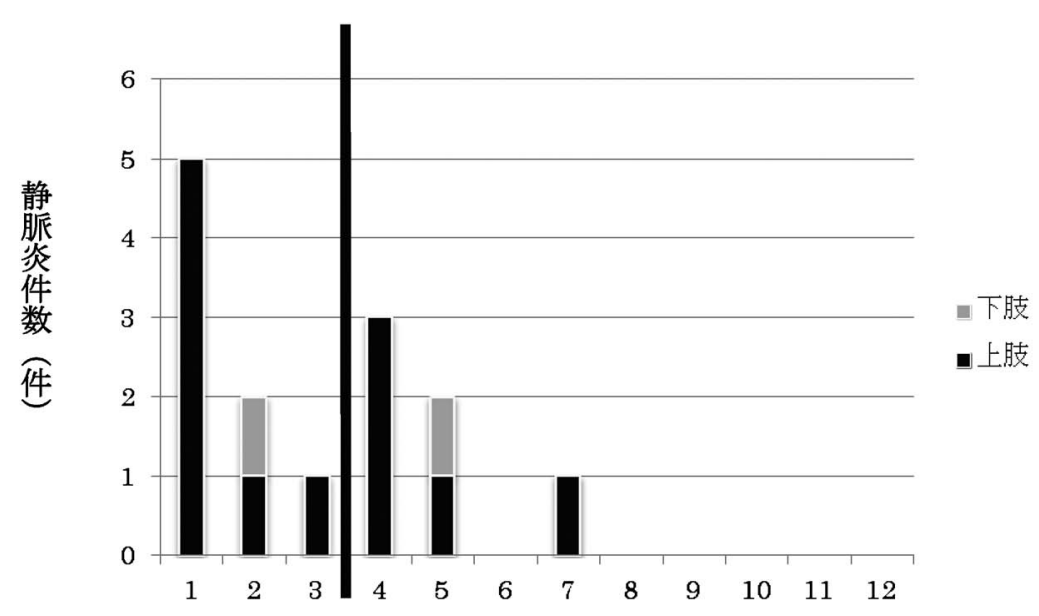

留置日数 (日)

図 2 静脈炎発生(INS 基準: $2+$ 以上)までの留置日数と件数と留置部位(当院)

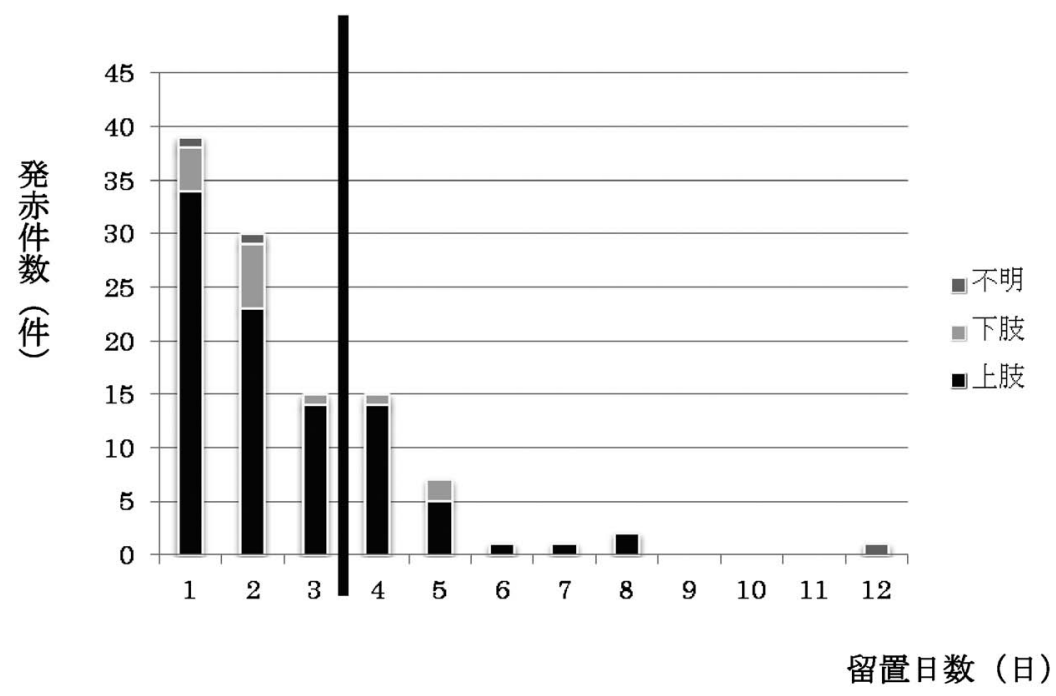

図 3 発赤発生までの留置日数と件数と留置部位(当院)

表 4 静脈炎発生率(INS 基準 : $2+$ 以上)（当院）

\begin{tabular}{lcccc}
\hline 留置日数 & $\begin{array}{c}\text { ライン使用 } \\
\text { 本数 }\end{array}$ & $\begin{array}{c}\text { 静脈炎発生 } \\
\text { 件数 }\end{array}$ & $\begin{array}{c}\text { 静脈炎 } \\
\text { 炎傎 }\end{array}$ & $\mathrm{p}$ 值* \\
\hline 1 3 日 & 694 & 8 & $1.1 \%$ & $\mathrm{p}=0.37$ \\
\hline 4 日以上 & 295 & 6 & $2 \%$ & \\
\hline$*$ フィッシャ一直接確率 & & &
\end{tabular}

の合併症につながるわけではなく，そして，コストを 削減できたと述べている．Guideline2002 から Guideline2011への推奨事項変更は, これらの研究に基づい て行われたと言える.

当院で末梢ラインの留置期間を 4 日毎から 7 日毎に 変更するにあたり，これまでに当院で実施していた末梢 ラインサーベイランス ${ }^{7}$ と全国の十数施設が参加する末
表 5 発赤発生率(INS 基準 : 1+以上) (当院)

\begin{tabular}{lcccc}
\hline 留置日数 & $\begin{array}{c}\text { ライン使用 } \\
\text { 本数 }\end{array}$ & $\begin{array}{c}\text { 発赤棨生 } \\
\text { 件数 }\end{array}$ & $\begin{array}{c}\text { 発赤発生 } \\
\text { 率 }\end{array}$ & $p$ 值* \\
\hline 1 3 日 & 694 & 84 & $12 \%$ & $p=0.19$ \\
\hline 4 日以上 & 295 & 27 & $9 \%$ & \\
\hline$*$ フィッシャ一直接確率 & & & \\
\hline
\end{tabular}

梢ライン関連 BSI サーベイランス研究会のデータ8)も参 考にした.

研究期間中に発生した BSI は 2 件であり, 1000 ライ ン日あたり 0.72 件であった．末梢ライン関連 BSI サー ベイランス研究会の結果である, 1000 ライン日あたり 0.13 件と比較して高值である. 研究期間が短かったこ と, 起因菌が MRSA であった患者の背景として MRSA 
保菌者であったことも要因として考えられる，発生日は どちらも 3 日目であり, BSI 防止の観点から, 刺入部を 含め異常のない患者の末梢ラインを 3〜 4 日毎に刺し替 える必要はない。

また，静脈炎や発赤の発生率についても，末梢ライン 留置期間 3 日以内と 4 日以上を比較して有意差は見ら れなかった. 更に多くの分母から検討出来る末梢ライン 関連 BSI サーベイランス研究会のデータでも, 留置期 間 4 日以上でも静脈炎や発赤は多く発生していない. つまり, 静脈炎防止の観点からも, 刺入部を含め異常の ない患者の末梢ラインを 3〜 4 日毎に刺し替える必要は ない。

な㧍, 直近の研究では, オーストラリア・クイーンズ ランド州にある 3 つの病院が共同で行った研究におい て, 臨床的所見のある時に末梢静脈カテーテルを除去す ることでカテーテルの挿入に関連した不快感, 診療材料 とスタッフの労力の両方の多額の費用を避けることがで きた9)と述べられている.

Guideline2011 では, 静脈ラインの使用日数が 6 日を 超えると想定される場合は, 末梢挿入型中心静脈カテー テル $(\mathrm{PICC})$ を使用することが推奖されている1). しか し, 日本の医療環境に抏いて PICCに対する認知度は低 く，ほとんどの場合において末梢ラインを長期にわたり 使用されていると思われる，また，輸液セットやライン の交換も必要と考えられるが，Guideline2011 では中心 ラインに対する勧告として7日毎の交換を推奨してい る. そこで, 静脈ラインの使用日数が 6 日を超える場 合すべてを PICCに変更することは現実的ではないこと や輸液セットの交換時期も中心ラインに準ずると考える ことなどを勘案して当院では標準的な留置期間を 7 日 間と設定した。

\section{結論}

結論として, 末梢ラインに関連する BSI や静脈炎や 発赤の多くは, ライン刺入後 3 日以内に発生した. た，留置期間が 4 日以上でも，3 日以内に抜去されたラ インに比較して静脈炎やBSI は多く発生していない. 従って, 刺入部を含め異常のない患者の末梢ラインを 3 ～4 日毎に刺し替える必要はないと考えられた. よって， Guidelines2011の示すと打り成人では, 感染や静脈炎 のリスクを低減するために 72〜96 時間よりも頻回に末 梢力テーテルを交換する必要はなく1) 刺入部の観察を重
視した上で 7 日毎の刺し替えへの変更は，患者の苦痛 軽減やスタッフの労力削減を図る有意義な対策と考え る.しかし, 適切なカテーテル交換時期については, 今 後の研究が待たれる.

謝 辞 : 本研究を行うにあたりご協力いただきました院内のス タッフ, および末梢ライン関連感染サーベイランス研究会の皆 様に深謝致します.

\section{利益相反について : 利益相反はない，}

\section{文献}

1) O'Grady NP, Alexander M, Burns LA, Dellinger EP, Garland J, Heard SO, et al.: Guidelines for the prevention of intravascular catheter-related infections. Am J Infect Control 2011; 39 (4 Suppl 1): S1-34.

2) 森兼啓太訳 : サーベイランスのための CDC ガイドライ ン NHSN マニュアル 2011 年版. メディカ出版. 大阪, 2012.

3) O'Grady NP, Alexander M, Dellinger EP, Gerberding JL, Heard SO, Maki DG, et al.: Guidelines for the prevention of intravascular catheter-related infections. Centers for Disease Control and Prevention. MMWR Recomm Rep 2002; 51(RR-10): 1-29.

4）長浜りか，遠藤和郎 : 末梢静脈カテーテル管理サーベイ ランスの試み. 環境感染 1999; 14(3): 192-5.

5）田中初美, 山本直美, 吉永喜久恵, 丹野恵一, 片岡陳 正 : 末梢静脈内留置カテーテルの菌検出状況から見たへ パリンロック管理の検討. 環境感染 2001; 16 (2): 15762.

6) Webster J, Lloyd S, Hopkins T, Osborne S, Yaxley M: Developing a research base for intravenous peripheral cannula re-sites (DRIP trial). A randomised controlled trial of hospital in-patients. Int J Nurs Stud 2007; 44: 664-71.

7）多湖ゆかり，谷 久弥，森兼啓太 : 末梢静脈カテーテル 関連 BSI サーベイランスによる末梢静脈カテーテル留 置期間の検討. 環境感染誌 2012; 27(Suppl): 263.

8）森兼啓太, 内田美保, 大久保真由美, 加藤由紀子, 黒須 一見，菅野みゆき，他 : 末梢ライン関連感染サーベイラ ンスによる留置中の合併症の傾向と対策. 環境感染誌 2012; 27 (Suppl): 263.

9) Rickard CM, Webster J, Wallis MC, Marsh N, McGrail MR, French V, et al.: Routine versus clinically indicated replacement of peripheral intravenous catheters: a randomised controlled equivalence trial. Lancet 2012; 380: 1066-74.

〔連絡先： $=522-8539$ 滋賀県彦根市八坂町 1882 番地 彦根市立病院感染対策室 多湖ゆかり E-mail: kansen@municipal-hp.hikone.shiga.jp] 


\title{
Relevance of The Duration of Peripheral Intravenous Catheterization to Bloodstream Infection and Phlebitis
}

\author{
Yukari TAGO ${ }^{1,2)}$, Hisami TANi ${ }^{1)}$ and Keita MorikAnE ${ }^{2,3}$ \\ 1) Infection Control Team, Hikone Municipal Hospital, \\ 2) Peripheral Intravenous Catheter-related Infections Surveillance Study Group, \\ ${ }^{3)}$ Division of Infection Control, Yamagata University Hospital
}

\begin{abstract}
We changed our practice on the standard duration of peripheral intravenous catheterization (PIC) from 4 days to 7 days, following the publication of the revised Guidelines for the Prevention of Intravascular Catheter-Related Infections by the US Centers for Disease Control and Prevention. Data regarding the incidence of bloodstream infections (BSIs) and phlebitis related to PIC during the 6 months after revision of the practice were collected and analyzed. Two BSIs were observed among 989 lines during 2,784 total line days, resulting in an incidence of 0.72 per 1000 line days. Both BSIs occurred on the third day of catheterization. Fourteen cases of phlebitis were detected. The incidence of phlebitis was similar within three days after catheterization and thereafter. Therefore, routine replacement of the catheter on the third to fourth day of PIC was not necessary. Replacement of the catheter on the seventh day is recommended to reduce the pain of procedures caused to the patient as well as the burden on the healthcare staff.
\end{abstract}

Key words : peripheral intravenous catheter, bloodstream infection, phlebitis, surveillance, duration of catheterization 